\title{
Body Distribution of Galactose-Containing Synthetic Polymer and Galactosylated Albumin
}

\author{
Yoshiyuki Koyama, Miki IshiKawa, Akihiko Ueda, \\ Tomohiro Sudo, Shuji KoJima, \\ and Akinori SUGINAKA* \\ Research Institute for Biosciences, Science University of Tokyo, \\ Noda-shi, Chiba 278, Japan \\ *NOF Corporation, Yuraku-cho 1-10-1, Chiyoda-ku, Tokyo 100, Japan
}

(Received July 10, 1992)

\begin{abstract}
A water-soluble polymer having galactose pendant groups was prepared by the synthesis and radical polymerization of $p$-vinylbenzyl galactoside. Copolymerization of the galactoside with $p$-vinylphenyl acetate and subsequent $\left[{ }^{125} \mathrm{I}\right]$ labeling by a chloramine-T method afforded a radio-labeled galactose-containing polymer, and the body distribution of the polymer in mice was examined along with that of galactosylated bovine serum albumin (BSA). Both $\left[{ }^{125} \mathrm{I}\right]$ labeled galactose-containing polymer and $\left[{ }^{14} \mathrm{C}\right]$ labeled galactosylated BSA highly accumulated in the liver $(>90 \%)$ soon after intravenous administration. The excretion of the synthetic vinyl polymer from the liver was very slow, and $92 \%$ and $63 \%$ of the administered radioactivity still remained in the liver 2 and $24 \mathrm{~h}$ after the injection, respectively, while only $18 \%$ of the radioactivity was recovered $2 \mathrm{~h}$ after the injection of $\left[{ }^{14} \mathrm{C}\right]$ labeled galactosylated BSA.

KEY WORDS Galactose-Containing Polymer / Galactosylated Albumin / Poly(ethylene glycol) / Body Distribution / Radioisotopes /
\end{abstract}

Various sugar-binding proteins, i.e., lectins, have been found not only in plant tissues, but also in some mammalian cell surfaces. Sugar-specificity of the lectins and their tissue specific distribution in the body seem to make it possible to design targetable drug-carriers by the incorporation of the sugar residues into macromolecular drug-carriers as determinants.

Since galactose-binding proteins were reported in mammalian hepatocytes by Ashwell and Morell, ${ }^{1}$ liver-targeting by galactosecontaining drug-carriers such as liposomes, ${ }^{2}$ proteins, ${ }^{3}$ and synthetic polymers, ${ }^{4}$ has been attempted. These galactosylated materials successfully accumulated in the liver soon after intravenous injection:

$\left[{ }^{99 m} \mathrm{Tc}\right]$ Labeled galactosylated human serum albumin was also prepared, and clear radioscintigrams of the healthy and cancerous liver were obtained $10 \mathrm{~min}$ after injection. ${ }^{5,6}$
Fairly fast excretion of the radioactivity from the liver was always observed after accumulation of radiolabeled galactosylated proteins, probably due to the degradation of the proteins in the liver or slipping off of the radionuclide from the proteins.

Fast excretion of the radioactivity from the tissue is desired for radiopharmaceuticals in order to avoid undesired internal radiation, and it is not much important to know whether this fast clearance of the radioactivity is caused by the degradation of the proteins, or the slipping off of reporting nuclei or groups. On the other hand, as for drug-targeting carriers, moderately long retention of polymers in organs is desirable for the durable release of drugs in tissue.

Vinyl polymers in which a stable carboncarbon covalent linkage forms the main chain are thought to resist being biodegraded, and 
expected to remain in the tissue for a long time. Our previous study on the body distribution of glucose-containing vinyl polymers also supports this speculation. This polymer quickly accumulated in the liver and spleen, and remained in these tissues over $24 \mathrm{~h}^{7}$.

In this study, we synthesized the watersoluble polymer containing galactose side chains, and examined its possibility as a durable drug-carrier compared with that of galactosylated bovine serum albumin.

\section{EXPERIMENTAL}

\section{Materials}

p-Chloromethylstyrene was provided by Hodogaya Chemical Co., Ltd. p-Vinylphenyl acetate was given by Maruzen Oil Co., Ltd. $\left[{ }^{125} \mathrm{I}\right] \mathrm{NaI}$, and $\left[{ }^{14} \mathrm{C}\right]$ labeled bovine serum albumin were purchased from Daiichi Pure Chemical Co., Ltd. $\left[{ }^{13} \mathrm{C}\right]$ Labeled poly(ethylene glycol) 4000 and $\left[{ }^{111} \mathrm{In}\right] \mathrm{InCl}_{3}$ were obtained from Amersham Co., Japan Ltd. and from Nihon Mediphysics, respectively.

\section{Synthesis of $p$-Vinylbenzyl $\beta$-D-Galactoside $(V B G)$}

$2,3,4,6$-Tetra- $O$-acetyl- $\alpha$-D-galactosyl bromide was prepared according to the standard method by treatment of penta-acetylated galactose with hydrogen bromide in acetic acid $^{8}$ except for adding acetic anhydride to a $\mathrm{HBr}$ solution in acetic acid in advance so as to remove water.

$p$-Vinylbenzyl alcohol was prepared from $p$-chloromethylstyrene as previously reported, ${ }^{7}$ and was galactosylated by a Koenings-Knorr method in a similar manner to the glucoside ${ }^{7}$ as follows: $p$-Vinylbenzyl alcohol $(10.7 \mathrm{~g})$, silver carbonate $(25 \mathrm{~g})$, drierite $(25 \mathrm{~g})$, and $125 \mathrm{ml}$ of ether were mixed and stirred magnetically for $1 \mathrm{~h}$. Acetobromogalactose $(25 \mathrm{~g})$ in $125 \mathrm{ml}$ of ether was added to the mixture, and it was stirred overnight. The mixture was filtered, and the filtrate evaporated to a syrup. It was dissolved in $0.1 \mathrm{~N}$ sodium methoxide in methanol $(200 \mathrm{ml})$, and after standing for $3 \mathrm{~h}$, the reaction solution was neutralized by Amberlite IRC-84 (-COOH type), and evaporated. The residual syrup was washed by petroleum ether, and extracted by acetone. After removal of the solvent, a pale yellow syrup was washed by petroleum ether, and extracted by acetone. After removal of the solvent, a pale yellow syrup was washed by petroleum ether, crystallized from ethanol +petroleum ether to colorless thin plates. Yield, 0.23 g. $\mathrm{mp} 99.5-103^{\circ} \mathrm{C}{ }^{1} \mathrm{H}$ NMR (DMSO- $d_{6}$ ): $\delta$ (in ppm) 7.44 and 7.37 (two d, $4 \mathrm{H}$, aromatic $-\mathrm{CH}=), 6.73(\mathrm{dd}, 1 \mathrm{H}$, vinyl $=\mathrm{CH}-), 5.82$ and 5.24 (two dd, $2 \mathrm{H}$, vinyl $\mathrm{CH}_{2}=$ ), $4.94-4.36$ (m, $4 \mathrm{H}, 2,3,4,6-\mathrm{OH}$ ), 4.80 and 4.57 (two d, $2 \mathrm{H}$, benzyl $\left.-\mathrm{CH}_{2}-\right), 4.18(\mathrm{~d}, 1 \mathrm{H}, \mathrm{H}-1), 3.65-3.25$ $(\mathrm{m}, 6 \mathrm{H}, \mathrm{H}-2,3,4,5,6)$.

\section{Polymerization}

Copolymer of VBG and p-vinylphenyl acetate (VPA) was prepared by radical copolymerization. VBG (134 mg, $0.45 \mathrm{mmol}$ ), VPA $(8.1 \mathrm{mg}, 0.05 \mathrm{mmol}), \alpha, \alpha$-azobisisobutyronitrile (AIBN), a radical initiator, $(0.8 \mathrm{mg}$, $0.005 \mathrm{mmol}$ ), and $0.5 \mathrm{ml}$ of dry dimethylsulfoxide were charged in a glass tube. The content was frozen by liquid nitrogen and degassed three times. The tube was sealed under vacuum, and put in a temperature-constant bath at $60^{\circ} \mathrm{C}$. After $1 \mathrm{~h}$, the viscous solution was poured into a mixture of acetone + ether (1:1) to precipitate the polymer, which was thoroughly washed by the same solvents and dried in vacuo. Yield, $23.3 \mathrm{mg}$.

\section{$\left[{ }^{125}\right]$ Labeling the Copolymer}

The copolymer $(50 \mu \mathrm{g})$ was dissolved in phosphate-buffered saline (PBS; pH 7.4) by gentle warming, and was $\left[{ }^{125} \mathrm{I}\right]$ labeled by a conventional chloramine- $\mathrm{T}$ method. The radioiodinated polymer was purified by gel filtration using a Sephadex G-50 column and PBS as an eluent. 
Galactosylation of Bovine Serum Albumin

Bovine serum albumin (BSA) was galactosylated by the imidoester method, ${ }^{9}$ briefly as follows. Cyanomethyl 2,3,4,6-tetra- $O$-acetyl-1thio- $\alpha$-D-galactopyranoside $(20 \mathrm{mg})$ was dissolved in dry methanol $(0.5 \mathrm{ml})$, and $1 \mathrm{mg}$ of $28 \%$ sodium methoxide in methanol was added to the solution. After standing overnight at $37^{\circ} \mathrm{C}$, the reaction mixture was evaporated to a solid. BSA $(2 \mathrm{mg})$ in $0.2 \mathrm{ml}$ of $0.1 \mathrm{M}$ boronate buffer ( $\mathrm{pH}$ 9.0) was added to the residue, and the mixture was left standing overnight at $\mathrm{rt}$. The polymeric product was purified by repeating ultafiltration and adding PBS.

$\left[{ }^{14} \mathrm{C}\right]$ Labeled BSA $(1 \mu \mathrm{Ci}, 42 \mu \mathrm{g})$ was similarly galactosylated using $20 \mathrm{mg}$ of cyanomethyl acetylthiogalactoside. The product was purified by gel filtration using a Sephadex G-50.

$\left[{ }^{125} \Gamma\right.$ Labeling the Galactosyllated BSA (G$B S A$ )

G-BSA was $\left[{ }^{125} \mathrm{I}\right]$ labeled in the same way as for copoly(VBG-VPA). The radiolabeled G-BSA was purified by gel filtration using a Sephadex G-50 and PBS as an eluent.

\section{$\left[{ }^{111} I n\right]$ Labeling the $G-B S A$}

Diethylenetriaminepentaacetic (DTPA) dianhydride $(1.0 \mathrm{mg})$ and $0.25 \mathrm{ml}$ of $0.2 \mathrm{M}$ sodium bicarbonate aq. were added to the solution of G-BSA $(250 \mathrm{mg})$ in PBS $(0.25 \mathrm{ml})$. After standing for $1 \mathrm{~h}$, the unreacted DTPA was removed by repeated ultrafiltration and adding $0.01 \mathrm{M}$ acetate buffer ( $\mathrm{pH}$ 6.0). $\left[{ }^{111} \mathrm{In}\right] \mathrm{Cl}_{3}$ in saline was added to the DTPA-conjugated G-BSA solution in the acetate buffer, and after $30 \mathrm{~min}$, the $\left[{ }^{111} \mathrm{In}\right]$ labeled G-BSA was purified by gel filtration using a Sephadex G-50 and PBS.

\section{Body Distribution of the Radio-Labled Polymers and the $G$-BSAs}

Male ddY mice (7-9 weeks old) weighing about $30-35 \mathrm{~g}$ were injected with the radiolabeled polymer ( $5 \mu \mathrm{g}$ in $0.2 \mathrm{ml}$ PBS) or protein (3-8 $\mu \mathrm{g}$ in $0.1 \mathrm{ml}$ PBS) via the tail vein. After a given time, the mice were killed and the organs removed, weighed, and assayed for radio-activity.

\section{Measurements}

${ }^{1} \mathrm{H}$ NMR spectra were measured in $\mathrm{Me}_{2} \mathrm{SO}$ $d_{6}$ with a VARIAN VXR-500S. Tetramethylsilane was used as the internal standard.

$\gamma$-Radioactivity of the organs was determined with a scintillation counter (Aloka ARC 300). $\beta$-Activity of the tissues after injection of $\left[{ }^{14} \mathrm{C}\right] \mathrm{G}-\mathrm{BSA}$ or $\left[{ }^{14} \mathrm{C}\right]$ poly(ethylene glycol) was determined as follows. The tissues were burned in oxygen, and generated $\left[{ }^{14} \mathrm{C}\right] \mathrm{CO}_{2}$ was absorbed by monoethanolamine, and assayed with a liquid scintillation counter (Aloka LSC-3600).

A gel permeation chromatogram was measured with a Toyo Soda high-speed liquid chromatograph (HLC-802). The molecular weight of the polymer was calculated using pullulan as the standard sample.

The diameter of the copolymer in water $(0.2 \%$ solution) was measured by a submicron particle sizer NICOMP $370 \mathrm{HPL}$ at $23^{\circ} \mathrm{C}$.

\section{RESULTS AND DISCUSSION}

p-Vinylbenzyl galactoside (VBG) was synthesized from $p$-vinylbenzyl alcohol and acetobromogalactose by a standard KoenigsKnorr method. In the ${ }^{1} \mathrm{H}$ NMR spectrum of glycoside in DMSO- $d_{6}$, only one $\mathrm{H}-1$ peak appeared. The formation of 1,2-cis-glycoside in such reaction is reported to be kinetically unfavorable. ${ }^{10}$ The coupling constant between

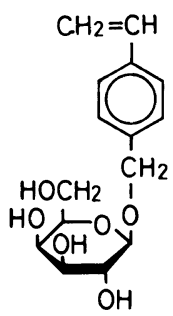

Figure 1. Structure of $p$-vinylbenzyl $\beta$-D-galactoside (VBG). 
$\mathrm{H}-1$ and $\mathrm{H}-2$ in the NMR spectrum was $7.6 \mathrm{~Hz}$, being consistent with that reported for $\beta$-D-galactoside in $\mathrm{D}_{2} \mathrm{O}(7.5 \mathrm{~Hz})$, while that of $\alpha$-D-galactoside was $3.2 \mathrm{~Hz}$. Thus, the $\beta$ anomer is thought to be formed.

VBG was easily copolymerized with $p$ vinylphenyl acetate (VPA) in dimethylsulfoxide by $\alpha, \alpha$-azobisisobutyronitrile as an initiator to a white powderous copolymer. The composition of the copolymer was determined by $500 \mathrm{MHz}{ }^{1} \mathrm{H}$ NMR spectrum, and the molar ratio of VBG:VPA was $92: 8$. The number average molecular weight $\left(\bar{M}_{n}\right)$ and weight average molecular weight $\left(\bar{M}_{w}\right)$ were measured by a gel permeation chromatography as 176000 and 432000 , respectively.

Copoly(VBG-VPA) is soluble in dimethylsulfoxide, dimethylformamide, and warm water, and insoluble in acetone, ether and alcohol. Once the polymer was dissolved in water by warming, no precipitate was formed on cooling.

Copoly(VBG-VPA) containing acetoxyphenyl groups was readily $\left[{ }^{125} \mathrm{I}\right]$ labeled in a labeling efficiency of $17 \%$ by a conventional chloramine-T method.

\section{Body distribution of galactosylated BSA (G- $B S A$ )}

The body distribution of G-BSA was examined prior to that of Copoly(VBG-VPA). $\left[{ }^{125} \mathrm{I}\right]$ labeled G-BSAs were first prepared and used in the body distribution study.

As shown in Figure 2, rapid and high hepatic uptake was observed for both G-BSAs, and $50 \%$ and $60 \%$ of the administered radioactivity were recovered in the liver $10 \mathrm{~min}$ after the injection of $\left[{ }^{125} \mathrm{I}\right]$ - and $\left[{ }^{111} \mathrm{In}\right]$ labeled GBSAs, respectively. But the excretion rate of radioactivity from the tissue was much varied depending on the radionuclide. Very rapid clearance of the activity from the liver was seen with $\left[{ }^{125} \mathrm{I}\right] \mathrm{G}-\mathrm{BSA}$, and only $6 \%$ of the administered radioactivity remained in the liver after $2 \mathrm{~h}$. Injection of $\left[{ }^{111} \mathrm{In}\right]$ labeled G-BSA resulted in long retention of activity in the

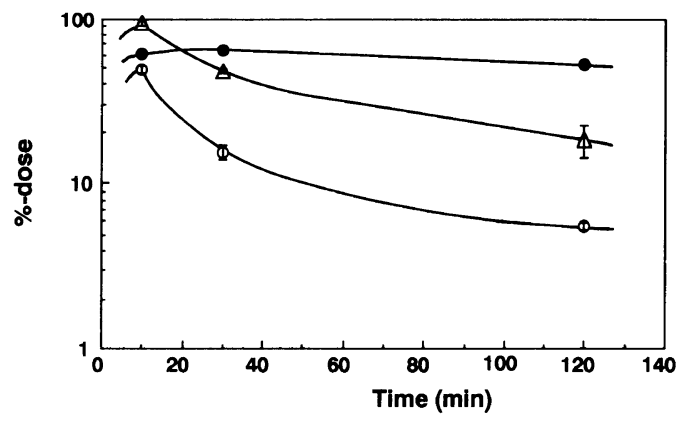

Figure 2. Radioactivity recovered in the liver after intravenous administration of $\left[{ }^{125} \mathrm{I}\right]-\mathrm{G}-\mathrm{BSA}(\mathrm{O}),\left[{ }^{111} \mathrm{In}\right]-$ DTPA-G-BSA $(\bigcirc)$, and $\left[{ }^{14} \mathrm{C}\right]$ methyl-G-BSA $(\triangle)$. Each point represents the mean \pm standard error of at least three observations.

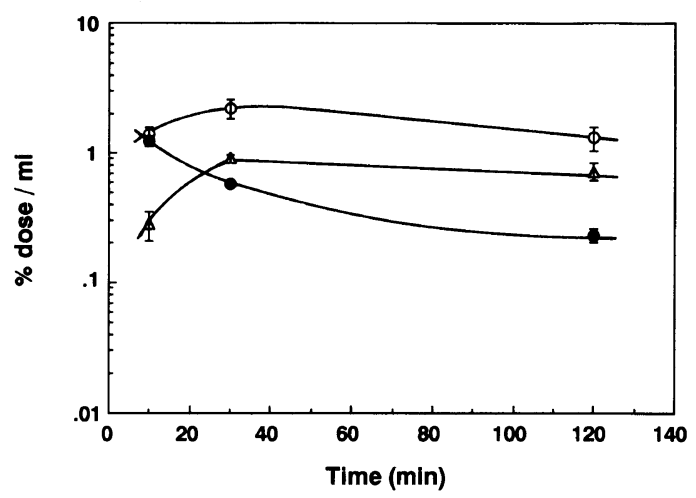

Figure 3. Radioactivity recovered in the blood after the intravenous administration of $\left[{ }^{125} \mathrm{I}\right]-\mathrm{G}-\mathrm{BSA}(\mathrm{O}),\left[{ }^{111} \mathrm{In}\right]$ DTPA-G-BSA $(\bigcirc)$, and $\left[{ }^{14} \mathrm{C}\right]$ methyl-G-BSA $(\triangle)$. Each point represents the mean \pm standard error of at least three observations.

organ.

There be two possible reasons for this significant difference in the excretion rate: One is deiodination of $\left[{ }^{125} \mathrm{I}\right] \mathrm{G}-\mathrm{BSA}$ by enzymes in the liver, followed by the fast clearance of separated free radioiodines. The gradual increase of the radioactivity in the thyroid seems to support the occurrence of the dehalogenation reaction (Figure 4). The other reason is the transchelation of $\left[{ }^{111} \mathrm{In}\right]$ nuclei from the DTPA residues in G-BSA to chelating organic materils in the liver. Thus, it was thought that the real body distribution and the retention of G-BSA could not be evaluated by 


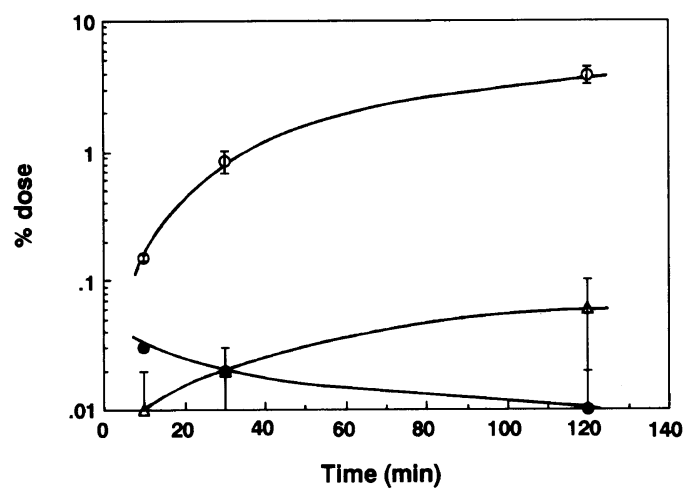

Figure 4. Radioactivity recovered in the thyroid after intravenous administration of $\left[{ }^{125} \mathrm{I}\right]-\mathrm{G}-\mathrm{BSA}(\mathrm{O}),\left[{ }^{111} \mathrm{In}\right]-$ DTPA-G-BSA $(\bigcirc)$, and $\left[{ }^{14} \mathrm{C}\right]$-methyl-G-BSA $(\triangle)$. Each point represents the mean \pm standard error of at least three observations.

results obtained by $\left[{ }^{111} \mathrm{In}\right]-$ and $\left[{ }^{125} \mathrm{I}\right]$ labeled G-BSAs.

Thus, the G-BSA containing unremovable radionuclide, was desired to know the real retention of G-BSA in the liver. $\left[{ }^{14} \mathrm{C}\right]$ labeled G-BSA was then synthesized by glycosylation of [methyl- $\left.{ }^{14} \mathrm{C}\right]$ methylated BSA prepared by the methylation of BSA using $\left[{ }^{14} \mathrm{C}\right]$ formaldehyde, followed by reduction by sodium cyanoborohydride, and body distribution of the galactosylated $\left[{ }^{14} \mathrm{C}\right] \mathrm{BSA}$ was examined.

High and rapid hepatic uptake was also observed, and $96 \%$ of the administered radioactivity was found in the liver at $10 \mathrm{~min}$ post injection. The radioactivity in the liver then decreased at a moderate excreting rate, and $18 \%$-dose remained after $2 \mathrm{~h}$. This clearance of activity from the liver was faster than that with $\left[{ }^{11} \mathrm{In}\right]$ labeled G-BSA, and slower than that with $\left[{ }^{125} \mathrm{I}\right]$ labeled one.

The uptake of $\left[{ }^{14} \mathrm{C}\right] \mathrm{G}-\mathrm{BSA}$ by the liver during the first $10 \mathrm{~min}$ was higher than those of $\left[{ }^{111} \mathrm{In}\right]-$ and $\left[{ }^{125} \mathrm{I}\right] \mathrm{G}-\mathrm{BSAs}$. The reason for the difference is still not clear. The methylation of the BSA might affect its distribution. The very high molar ratio $(>80000)$ of the cyanomethyl acetylgalactoside to the $\left[{ }^{14} \mathrm{C}\right] \mathrm{BSA}$ in the galactosylation reaction may result in high sugar content in the G-BSA molecule, which would cause higher hepatic uptake. ${ }^{12}$ The amount of the galactosylated $\left[{ }^{14} \mathrm{C}\right] \mathrm{BSA}$ was, however, too small $(42 \mu \mathrm{g})$ to characterize its sugar content or other properties.

Since there may be no possible mechanisms for slipping off of $\left[{ }^{14} \mathrm{C}\right]$ methyl groups from the protein, the fairly rapid excretion of the radioactivity from the liver after the accumulation of $\left[{ }^{14} \mathrm{C}\right] \mathrm{G}-\mathrm{BSA}$ must be due to the degradation of protein in the hepatocytes. The long retention with $\left[{ }^{11} \mathrm{In}\right] \mathrm{G}-\mathrm{BSA}$ may be caused by the transchelation of the radionuclide to natural chelating materials such as heparan sulfate present in the liver in a large amount and found to strongly bind to metal cations. ${ }^{13}$ Deiodination also seems to occur and cause the rapid clearance of radioactivity after the accumulation of $\left[{ }^{125} \mathrm{I}\right] \mathrm{G}-\mathrm{BSA}$ in the liver. These two reasons will cause difference in the excretion rate of G-BSAs depending on the radionuclide.

BSA was efficiently delivered to the liver by galactosylation of the protein, but long duration, sometimes favorable especially for a slow drug-releasing carrier, would not be possible by this method because of the biodegradability of the protein molecule in the organ.

\section{Body Distribution of Copoly $(V B G-V P A)$}

Synthetic vinyl polymers have a main chain consisting of carbon-carbon covalent bonds which would not be biodegraded, so they could be expected to show long duration in tissues. Radiolabled copoly(VBG-VPA) was prepared for a body distribution study.

As shown in our previous study, ${ }^{7}\left[{ }^{125} \mathrm{I}\right]$ labeling of the VPA residue in the glucosecontaining polymer, which has a similar structure to copoly(VBG-VPA) except the configuration of the sugar pendant, was stable in both serum and the liver, and a long retention of radioactivity was seen with $\left[{ }^{125} \mathrm{I}\right]$ labeled copolymer with VPA residues.

Thus, $\left[{ }^{125}\right.$ I]labeling seems useful for VPA- 


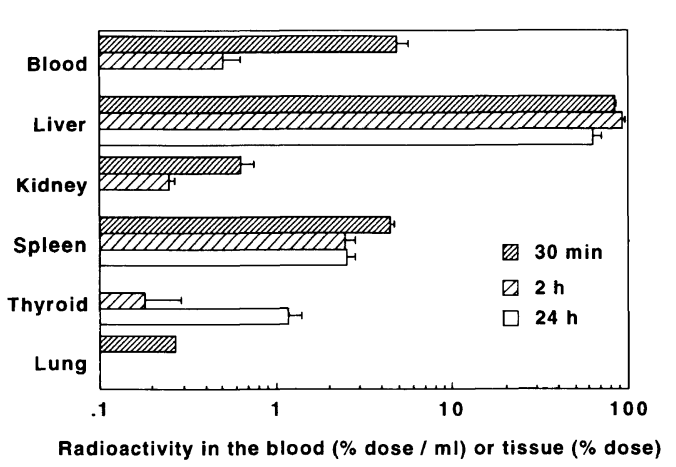

Figure 5. Radioactivity recovered in the blood and tissues after intravenous administration of $\left[{ }^{125} \mathrm{I}\right]$ labeled copoly(VBG-VPA). Each column represents the mean \pm standard error of three observations.

copolymers, though is not suitable in the duration study of proteins. Copoly(VBG-VPA) was then labeled by $\left[{ }^{125} \mathrm{I}\right]$, and its body distribution was studied.

$\left[{ }^{125} \mathrm{I}\right]$ Labeled copoly(VBG-VPA) was also delivered mostly to the liver soon after intravenous injection as well as galactosylated BSAs, and $84 \%$-dose of the radioactivity was recovered in the liver $30 \mathrm{~min}$ after the injection (Figure 5). Relatively high accumulation was observed in the spleen (4.4\%), kidney $(0.64 \%)$ and lung $(0.27 \%)$, and radioactivity recovered in the heart, pancreas, stomach, brain was not more than $0.1 \%$-dose.

A long duration of the copolymer in the liver was observed as expected, and activity in the liver increased to $92 \%$-dose in $2 \mathrm{~h}$ after injection. After $24 \mathrm{~h}, 63 \%$ of the administered activity was still in the liver, showing not only duration of the copolymer in the organ, but also stability of the $\left[{ }^{125} \mathrm{I}\right]$ labeled copolymer in the tissue, contrary to rapid deiodination seen with $\left[{ }^{125} \mathrm{I}\right]$ labeled G-BSA.

The copolymer consists of an amphiphilic repeating unit, and, thus, would have a compact conformation with hydrophobic aromatic groups inside the particle in water. This may prevent the approach of deiodinizing enzymes to iodinated VPA residues. Acetyl groups at the phenolic hydroxyls may also delayed deiodination.

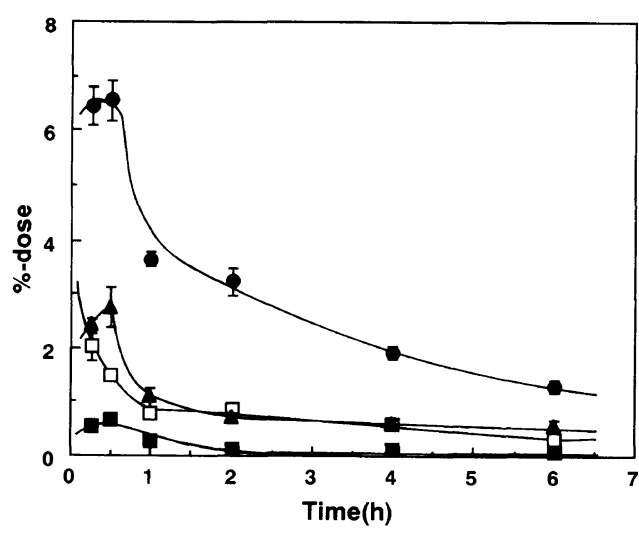

Figure 6. Radioactivity recovered in the liver ( $)$, kidney ( $\Delta), 1 \mathrm{ml}$ of the blood $(\square)$, and $1 \mathrm{~g}$ of the muscle $(\square)$ after the intravenous administration of $\left[{ }^{14} \mathrm{C}\right]$ labeld poly(ethylene glycol) 4000 . Each point represents the mean \pm standard error of four observations.

The copolymer partly accumulated in the spleen, and aslo remained in the organ for long time. On the other hand, radioactivity in the lung, kidney, pancreas, and muscle rapidly decreased with time, most likely due to decrease in the concentration of the copolymer in the blood. The long retention of radioactivity in the liver and spleen should be due to pinocytotic internalization of the copolymer into the cells, while in the other organs the copolymer would exist outside or on the surface of the cells.

This high accumulation in the liver may be a general property of synthetic polymers, for the liver is an organs where the reticuloendothelial system (RES) exists. To examine whether high liver-uptake of the copoly(VBG-VPA) is due to sugar specific recognition or non-specific RES uptake, comparison should be made with body distribution behavior of other watersoluble polymers with no sugar residues. The polymer with the same back-bone structure as the copoly(VBG-VPA) with no sugar pendant is, not soluble in water. So we investigated the disposition of $\left[{ }^{14} \mathrm{C}\right]$ poly(ethylene glycol) 4000 , a bioinert, neutral polymer, and the results are illustrated in Figure 6.

Soon after injection $(15-30 \mathrm{~min})$, about $6 \%$ 
accumulation in the liver was observed. But it decreased gradually to $1 \%$ in $6 \mathrm{~h}$. A remarkable high accumulation was found in no organ.

The ratio of radioactivity recovered in the liver to that in $1 \mathrm{ml}$ of the blood (L/B ratio) ranged from 3.2 to 4.7 , while that for copoly(VBG-VPA) was 17 and 180 at 0.5 and $2 \mathrm{~h}$ after injection, respectively.

The difference in liver-uptake and $\mathrm{L} / \mathrm{B}$ ratio may be caused by differences in molecular weights of the polymers. But the number average diameter of the copoly(VBG-VPA) measured in water was as low as $6.4 \mathrm{~nm}$, and more than $90 \%$ of the molecule had a diameter smaller than $11 \mathrm{~nm}$. In our early study, it was found that liposomes with a size of smaller than $100 \mathrm{~nm}$ were unfavorable for RES uptake (unpublished). The diameter of the copoly(VBG-VPA) is still much less than the size favored by RES. Most reasonably, the recognition of the bioactive galactose residues by the hepatocytes would cause much higher uptake of the copoly(VBG-VPA) than poly(ethylene glycol), considering the similar high liver-uptake of galactosylated albumins. Such a high accumulation in the liver after the intravenous administration would be a characteristic of the galactose-containing macromolecules.

The high and rapid hepatic uptake and subsequent long retention of copoly(VBGVPA) suggests good applicability of the copolymer to liver-targeting and slow releasing drug-carriers. A conjugate of the galactosecontaining polymer and glutathione was then synthesized, in which glutathione was connected to the polymer through degradable $\mathrm{S}-\mathrm{S}$ linkages. This polymeric prodrug showed a remarkable protecting effect on the liver from $\mathrm{CCl}_{4}$-induced injury, and prevented GOT- and GPT-increase while free glutathione had no effect on these markers (data not shown).

Acknowledgements. The authors are grateful to Prof. Kondo, Prof. Kubodera, and Prof. Yoshida for their kind encouragment. We thank Dr. Chino and Mr. Kawaide for their skillful technical assistance. We also thank Hodogaya Chemical Co., Ltd. and Maruzen Oil Co., Ltd. for providing the chemicals.

\section{REFERENCES}

1. G. Ashwell and A. G. Morell, Adv. Enzymol., 41, 99 (1974).

2. H. Kiwade, H. Niimura, and Y. Kato, Chem. Pharm. Bull., 33, 2475 (1985).

3. Y. Ohtsubo, J. Ohno, M. Nishikawa, T. Fujita, M. Hashida, and H. Sezaki, Drug Delivery System, 6, 13 (1991).

4. R. Duncan, K. C. W. Seymour, L. Scarlett, J. B. Lloyd, P. Rejmanova, and J. Kopecek, Biochim. Biophys. Acta, 880, 62 (1986).

5. Y. Kubota, M. Kojima, H. Hazawa, S. Kawa, M. Nakazawa, Y. Nishiyama, S. Nakazawa, T. Murase, H. Okuno, Y. Naitoh, K. Washino, T. Hasegawa, T. Sawamura, Y. Tashiro, Y. Tanaka, Y. Shiozaki, and Y. Sameshima, Jpn. J. Nucl. Med., 23, 899 (1986).

6. M. Kudo, A. Todo, K. Ikekubo, M. Hino, H. Ito, H. Yamaguchi, Y. Saiki, K. Yamamoto, Y. Yonekura, K. Torizuka, K. Horiuchi, A. Yokoyama, D. R. Vera, and R. C. Standalnik, Jpn. J. Nucl. Med., 24, 1653 (1987).

7. Y. Koyama, M. Ishikawa, M. Iwamoto, and S. Kojima, J. Controlled Release, 22, 253 (1992).

8. L. J. Heynes and F. H. Newth, Adv. Carbohydr. Chem., 10, 207 (1955).

9. Y. C. Lee, C. P. Stowell, and M. J. Krantz, Biochemistry, 15, 3956 (1976).

10. A. F. Bochkov and G. E. Zaikov, "Chemistry of the O-Glycosidic Bond," Pergamon Press, Oxford, 1979, p 16.

11. K. Izumi, Agric. Biol. Chem., 35, 1816 (1971).

12. C. P. Stowell and Y. C. Lee, Adv. Carbohydr. Chem. Biochem., 37, 225 (1980).

13. Y. Hama, S. Kojima, and A. Kubodera, Jpn. J. Nucl. Med., 19, 855 (1982). 